\title{
Recognition of Two Formae Speciales of Erysiphe graminis by Wheat Cells
}

\author{
Yukio Tosa**, Kazuyuki Mise* and Jiko Shishiyama* \\ Key Words : Erysiphe graminis, forma specialis, cellular recognition, fluorescence micro- \\ scopy.
}

The powdery mildew fungus of cereals shows high specialization of parasitism which consists of the forma specialis level and the race level. In the previous papers, we have examined cytologically and chronologically defense reactions of barley cultivars to races of Erysiphe graminis f. sp. hordei ${ }^{1-4)}$, and f. sp. triticis) using fluorescence microscopy. In this study the same procedure was applied to the examination of wheat cell responses to the two formae speciales of E. graminis.

The wheat cultivars tested were Triticum aestivum (L.) Thell. cv. Norin No. 3, Norin No. 4, Norin No. 26, Norin No. 29, and Selkirk. Seven-day-old primary leaves were inoculated with E. graminis f. sp. tritici, culture t4 and E. graminis f. sp. hordei, race I or IX. Methods of growing plants, of providing with inocula, of inoculation with conidia, and of preparation of the specimens for the observation of plant cell responses were as described previously ${ }^{5}$. For the observation of fungal development before attempting penetration, collected leaves were directly mounted on glass slide with a few drops of alcoholic lactophenol containing $0.05 \%$ aniline blue. The stained specimens were observed under a Nikon fluorescence microscope equipped with blue exciter filter IF 410485 and absorption filter 515W.

Kita et al. ${ }^{3)}$ have reported four types of cellular responses of barley leaves during the course of primary penetration by E. graminis f. sp. hordei: type A) fluorescing of papilla associated with unsuccessful penetration; type $B_{1}$ ) aggregation and fluorescing of epidermal cytoplasm associated with unsuccessful haustorial formation; type $\mathrm{B}_{2}$ ) aggregation and delayed fluorescing of epidermal cytoplasm associated with the fluorescing and disorganization of prematured haustorium; and type C) no fluorescing of papilla or epidermal cytoplasm followed by the successful formation of matured haustorium. Similar responses were also observed in wheat leaves inoculated with E. graminis f. sp. tritici, culture t4 (Plate I-1, 2, 3). The fluorescence was bright yellow as that detected in barley leaves. In rare cases nonfluorescent papillae associated with unsuc-

\footnotetext{
* Faculty of Agriculture, Kyoto University, Kyoto 606, Japan 京都大学農学部

** Present address: Faculty of Agriculture, Kochi University, Nankoku, Kochi 783, Japan 高知大学農学部
}

1) Mayama, S. and Shishiyama, J. (1976). Ann. Phytopath. Soc. Japan 42 : 618-620. 2) Toyoda, H., Mayama, S. and Shishiyama, J. (1978). Phytopath. Z. 92:125-131. 3) Kita, N., Toyoda, H. and Shishiyama, J. (1981). Can. J. Bot. $59: 1761-1768.4$ 4) Tosa, Y. and Shishiyama, J. (1984). Ibid. 62 : 795-798. 5) Tosa, Y. and Shishiyama, J. (1984). Ibid. $62: 2114-2117$. 
Table 1. Responses of wheat leaves during the course of primary penetration by E. graminis f. sp. tritici, culture t4, $48 \mathrm{hr}$ after inoculation

\begin{tabular}{l|c|c|c|c|c}
\hline \multirow{2}{*}{ Cultivar } & \multirow{2}{*}{$\begin{array}{c}\text { Infection } \\
\text { type }^{\text {a) }}\end{array}$} & \multicolumn{4}{|c}{$\begin{array}{c}\text { Percentage } \\
\text { particular host } \begin{array}{c}\text { germlings inducing } \\
\text { response type }\end{array}\end{array}$} \\
\cline { 3 - 6 } & & $\mathrm{A}$ & $\mathrm{B}_{1}$ & $\mathrm{~B}_{2}$ & $\mathrm{C}$ \\
\hline Norin No. 29 & 0 & 11.9 & 78.8 & 2.0 & 7.3 \\
Norin No. 3 & 0 & 10.7 & 59.1 & 2.6 & 27.5 \\
Selkirk & 1 & 9.0 & 16.7 & 1.1 & 73.1 \\
Norin No. 26 & 4 & 5.1 & 2.3 & 0 & 92.6 \\
Norin No. 4 & 4 & 2.0 & 1.1 & 0 & 96.9 \\
\hline
\end{tabular}

a) Visual response to E. graminis f. sp. tritici, culture t4, 7 days after inoculation.

b) Mean value of three replications, in each of which about 500 germlings that attempted penetration on three leaves were counted.

c) Refer to the text.

Table 2. Responses of wheat leaves during the course of primary penetration by E. graminis $\mathrm{f}$. sp. hordei, race I, $48 \mathrm{hr}$ after inoculation

\begin{tabular}{l|c|c|c|c|c}
\hline \hline \multirow{2}{*}{ Cultivar } & \multirow{2}{*}{$\begin{array}{c}\text { Infection } \\
\text { type }\end{array}$} & \multicolumn{4}{|c}{$\begin{array}{c}\text { Percentage } \\
\text { particular host germlings inducing }\end{array}$} \\
\cline { 3 - 6 } & & $\mathrm{A}$ & $\mathrm{B}_{1}$ & $\mathrm{~B}_{2}$ & $\mathrm{C}$ \\
\hline Norin No. 29 & 0 & 8.0 & 86.1 & 4.8 & 1.1 \\
Norin No. 3 & 0 & 3.2 & 90.7 & 5.2 & 0.8 \\
Selkirk & 0 & 6.2 & 89.2 & 3.9 & 0.7 \\
Norin No. 26 & 0 & 2.6 & 63.8 & 9.6 & 23.9 \\
Norin No. 4 & 0 & 5.1 & 51.7 & 9.4 & 34.0 \\
\hline
\end{tabular}

a) Visual response to E. graminis f. sp. hordei, race I, 7 days after inoculation. b), c) Refer to Table 1 .

cessful penetration were also observed. Germlings which induced this type of response were counted among those inducing the type $A$ response in the present study. Table 1 shows percentage of the germlings inducing each of the four responses $48 \mathrm{hr}$ after inoculation. The incidence of the $\mathrm{A}$ response did not exceed $12 \%$ in any cultivar. On the other hand, that of the $B_{1}$ response increased with the degree of resistance: $1-2 \%$ in Norin No. 4 and No. 26 (infection type 4) and 60-70\% in Norin No. 3 and No. 29 (infection type 0 ). Consequently the percentage of the germlings that produced a normal primary haustorium decreased with increasing degree of resistance. The germling producing a normal haustorium formed a small hyphal colony $48 \mathrm{hr}$ after inoculation. In Selkirk about $40 \%$ of colonies were accompanied by fluorescent mesophyll cells (Plate I-4).

E. graminis f. sp. hordei, race I, on wheat cultivar Norin No. 4 germinated, formed appressoria, and attempted penetration as well as on barley cultivar Nepal (Fig. 1) which is susceptible to eleven races of the barley mildew fungus in Japan ${ }^{6)}$. Table 2

6) Hiura, U. (1960). Ber. Ohara Inst. Landwirtsch. Biol. Okayama Univ. $11: 235-300.7$ ) Johnson, L.E.B., Bushnell, W. R. and Zeyen, R. J. (1982). Can. J. Bot. 60 : 1068-1083. 


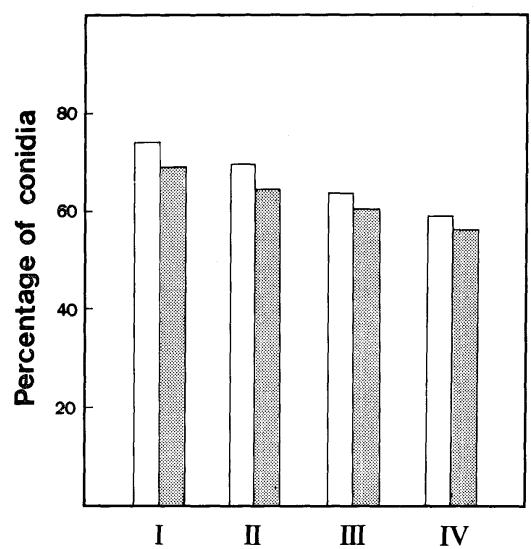

Fig. 1. Development of Erysiphe graminis f. sp. hordei, race I, on barley, cv. Nepal (open column), and on wheat, cv. Norin No. 4 (dotted column) 48 hr after inoculation. I: Conidia germinated, II: Conidia forming appressorium, III: Conidia inducing host responses (fluorescent halo, cell wall, and/or A-C responses), IV: Conidia inducing $\mathrm{A}-\mathrm{C}$ responses. Each value is mean of three replications, in each of which about 600 conidia on three leaves were counted. shows cellular responses of wheat cultivars to the primary penetration attempts by this fungus. The incidence of the A response was very low and did not exceed $10 \%$ in any cultivar. In Norin No. 29, Norin No. 3, and Selkirk most of the germlings that successfully penetrated cell wall induced the hypersensitive reaction of epidermal cells (the $B_{1}$ and $\mathrm{B}_{2}$ responses), and consequently failed to produce normal primary haustoria. In Norin No. 26 and Norin No. 4 the incidence of the $B_{1}$ respones was comparatively low, and 24 and $34 \%$ of total penetration attempts, respectively, resulted in the successful formation of normal primary haustoria. The germling producing a normal primary haustorium formed a small hyphal colony $48 \mathrm{hr}$ after inoculation. Its size was about $200 \mu \mathrm{m}$ in average, but the largest colony reached to $300 \mu \mathrm{m}$. Similar results were obtained in an experiment using $E$. graminis f. sp. hordei, race IX.

Johnson et al. ${ }^{7)}$ have suggested that the formation of papillae was important in the resistance of wheat to an inappropriate forma specialis, $E$. graminis f. sp. hordei. However, the present results showed that the essential factor in this resistance is not papilla formation but the hypersensitive reaction of epidermal cells. It should be noted that this defense pattern resembles that of highly resistant wheat cultivars against an appropriate forma specialis, E. graminis f. sp. tritici. This seems to be a very interesting fact in association with the definition of nonhost resistance ${ }^{8)}$. Similar facts have been noted by previous workers ${ }^{7-9)}$.

In barley cultivars inoculated with the wheat mildew fungus, as reported previously ${ }^{5)}$, papillae associated with unsuccessful penetration occurred more frequently than in them inoculated with the barley mildew fungus. Therefore, the recognition of the wheat mildew fungus by barley may not be equivalent to that of barley mildew fungus by wheat in the $A$ and $B_{1}$ responses.

We wish to thank Dr. U. Hiura, Institute of Agricultural Biology, Okayama University, for supplying barley seeds and powdery mildew fungi; and Dr. K. Tsunewaki, Laboratory of Genetics, Kyoto University, for supplying wheat seeds.

8) Heath, M. C. (1981). Plant Disease Control. John Wiley \& Sons, New York. p. 201-217. 9) White, N.H. and Baker, E. P. (1954). Phytopathology $44: 657-662$. 
和 文 摘 要

土俈幸雄・三顸和之・獅山慈孝 : Erysiphe graminis 二分化型のコムギ細胞による認識

コムギうどんこ病菌 Erysiphe graminis f. sp. tritici およびオオムギうごんこ病菌 E. graminis f. sp. hordei に対するコムギ葉の抵抗反応を螢光顕微鏡で観察した。まず, 抵抗性の程度の異なるコムギ 5 品種にf. sp. tritici 菌系 $\mathrm{t} 4$ 在幏種したところ, 螢光化パピラで侵入を阻止された胞子はいずれの品種においても12\% 以下乞低く, 強度抵抗性品種において抵抗性に重要な役割店果たしているのは表皮細胞の螢光化（過敏感反 応）であった。つぎに，てれらのコムギ 5 品種に f. sp. hordei レース I およびIXを接種したところ, 同様に いずれの品種においてす螢光化パピラで侵入を阻止さ机た胞子は10\%以下にとどまり，ほとんどの胞子が表皮 細胞の螢光化で生育を阻止されていた。このようなコムギ品種のオオムギうどんこ病菌に対する葉細胞におけ 乃抵抗反応とコムギうどんこ病菌に対するこの抵抗反応の類似性は，「非宿主抵抗性」を考える場合に興味深 い現象と考えられる。

(Received October 15, 1984)

\section{Explanation of plate}

\section{Plate I}

Cellular responses in wheat leaves $48 \mathrm{hr}$ after inoculation with E.graminis f. sp. tritici, culture $\mathrm{t} 4$.

1. Fluorescent papilla (FP) associated with a primary penetration attempt in cv. Norin No. 3. $\times 1500$.

2. Fluorescent epidermal cell (FEC) associated with a primary penetration in cv. Norin No. $3 . \times 270$.

3. Fluorescent epidermal cell (FEC) harboring a fluorescent haustorium (FH) in cv. Norin No. 3. $\times 780$.

4. Fluorescent mesophyll cells (FMC) underneath a hyphal colony in cv. Selkirk. $\times 260$.

\section{Plate I}
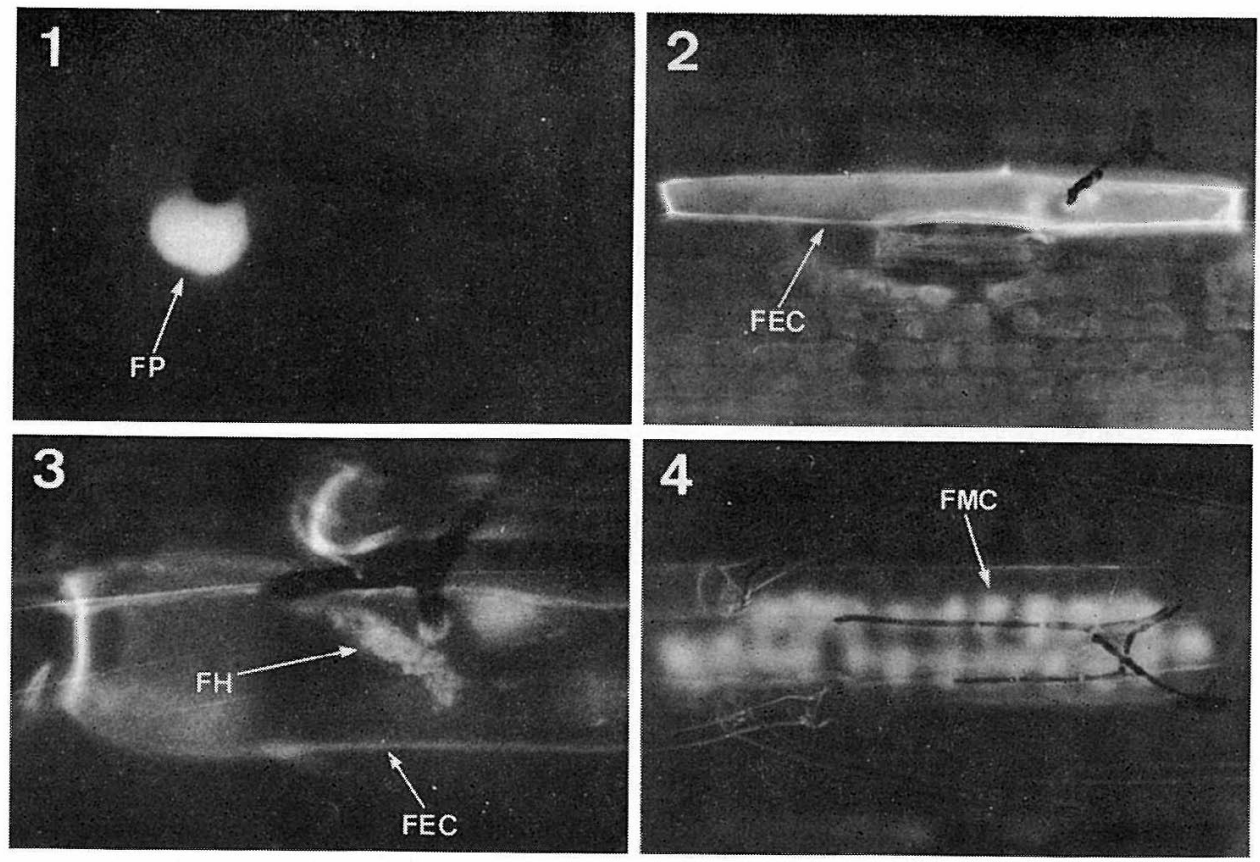